\title{
14 \\ In the Shadow of the Master Carver
}

\author{
Kate Fortune
}

Working with Brij Lal as assistant editor on the huge project that became The Pacific Islands: An Encyclopedia, published by University of Hawai' $\mathrm{i}$ Press in 2000, was in every way a wonderful, exhilarating, stimulating experience. My involvement began in 1996, when I was living in Canberra. I had been working in the Publications Branch of the National Library of Australia, when I saw an advertisement in the Canberra Times that caught my attention. In mid-June I went to be interviewed in the Coombs building at The Australian National University. Supplied with very specific directions by a helpful receptionist, I crossed the interior courtyard, climbed a series of stairwells and followed seemingly endless quaintly angled corridors. I am accustomed to navigational challengesorienteering is my chosen sport-but the honeycomb layout of Coombs building would test the resourcefulness of any explorer. Eventually, of course, it became familiar territory for me, but (even as a seasoned staff member) I never lost my original sense of delight that the best way to go down was sometimes to go up a few steps first (and probably to turn left initially if you needed to end up in a right-hand wing).

My employment at ANU commenced at the start of September 1996, with the title of Research Assistant: Pacific Islands Historical Encyclopedia at the Research School of Pacific and Asian Studies, and with an office right next to Brij Lal. From that very first morning, I arrived at work with 
a smile on my face, reading the names on each door and feeling as if I were skimming the shelves of the 'Pacific section' of the library. Donald Denoon, Hank Nelson, Deryck Scarr, Robert Langdon, Niel Gunson, Gerry Ward, Dorothy Shineberg, Darrell Tryon, Tom Dutton, Ron May; and also, in close proximity, Atholl Anderson, Bill Gammage, Matthew Spriggs, Peter Bellwood, Michael Bourke, Peter Dauvergne, Sinclair Dinnen, Bronwen Douglas, Geoffrey Hope, Kurt Lambeck, Ewan Maidment, Alan Rumsey, Peter Sack, Nicholas Thomas, Michael Young ... what a treasure trove of Pacific scholarship!

Brij's door was always open. We would have quick informal chats every few days, but the formal project development was achieved through our regular monthly sessions when the two of us made and confirmed plans, discussed progress, agreed on new directions and dealt with problems. The role of the full editorial board, chaired by Professor Donald Denoon, was also significant. At least three years before I joined the team, they had developed the concept of a Pacific encyclopedia and set the original parameters, devising a thematic approach—and they continued to have the final say on possible topics and contributors, as well as reviewing submissions. Board meetings were held quite frequently in the early days, but Brij himself always seemed to me to be the heart and soul of the project.

For the long duration of this project, Brij's clear focus and intelligent vision never wavered, and his enthusiasm remained steady. I cannot imagine a better colleague, quick to understand and unravel any confusing query I brought to him, constantly alert to a drifting current and aware of whatever correction was required to get us back on course. His vast knowledge of Pacific history is matched by a thorough understanding of cultural, political and economic issues, closely linked with a gifted teacher's ability to explain a broad context and define useful connections.

All these attributes were essential to the encyclopedia project, but in a way, none of them would have been sufficient without one further special talent. Brij is the most highly skilled and efficient networker I have ever encountered, and I am sure that is the key 'secret ingredient' in our final achievement. His contacts across the Pacific are apparently infinite, and he is tireless in maintaining them. As far as I can see, he remembers everyone who has ever crossed his path, every speaker at Pacific conferences, every university colleague from his whole career. I'm sure he still spends hours every day on the phone and on emails; he always did in my time, and could 
produce email addresses for anyone I needed to contact. If I reported to him that some potential contributor was unable to deliver the material we wanted, he would think about it briefly, then cheerfully come up with a fresh suggestion. If he couldn't identify a name instantly, he would supply it within 24 hours, occasionally perhaps after also consulting with someone else (like Max Quanchi) who had been involved in the project from the beginning.

Over time, I realised that Brij also maintains significant personal and social contacts in his own time. He and Padma work as an amazingly effective team, on a number of occasions hosting informal gatherings at their home. I was introduced to many visiting Pacific historians in this way, enjoying both the Lals' warm hospitality and the stimulating discussion of academic issues and political ideas on which Brij thrives. I especially recall an evening in honour of Kerry Howe, visiting from Auckland, when we relaxed in the garden under one of Canberra's glorious summer night skies.

On such memorable occasions, part of the enjoyment of the conversation arose from my awareness of Brij's keen intelligence and wide range of interests. I could see the respect in which he is held by his peers, and the way his articulate and thoughtful opinions are sought by those around him. I observed the way he provides useful feedback to other people on their research and writing, and I noted the appreciative response that such generous professional support invariably elicits.

Brij is astute in his judgements and wonderfully decisive. I very much appreciated this promptness and thoroughness in dealing with anything to do with the encyclopedia. When I provided him with copies of entries as they came in to the office, he was always quick either to advise on who else should read them, or to assess them himself and to comment on any that needed a supplementary article or just a little further information. Here, too, he was able to offer a range of possible names for me to contact, and his recommendations were always well chosen and wise.

Brij seems to have endless composure, superhuman patience and extraordinary diligence. University concerns, faculty budgets and academic business matters obviously impose considerable burdens (both time and energy) on senior staff members, added to normal teaching responsibilities on top of travel to conferences, etc. From my office next door, I observed his huge workload and came to have enormous respect for 
the effortless way he appeared to handle everything — while maintaining his own research and writing. I can't even imagine how he finds time to keep up his own formidable research output, because he is in constant demand as a speaker and a commentator, and those books and articles keep on appearing in print.

When it was time to take our vast project to a publisher, it was Brij's experience and his personal link to the University of Hawai' $i$ Press that streamlined the process and facilitated the production of a very handsome book. Our publishing editor, Pamela Kelley, clearly trusted Brij. He has earned a considerable-and well-deserved-reputation of delivering a quality product.

An encyclopedia of the Pacific Islands on this scale had never been attempted before (and in this new digital age may never be repeated). It seems to me it might be compared to the building of a large sea-going Māori waka (canoe) in the way it requires teamwork-with a variety of skills_-but also leadership, with everyone working under the guidance of the master carver. The vision behind the selection of the tree, the coordination to get the huge log conveyed to the right spot, the astute imagination behind the design, the strong emphasis on and respect for traditional techniques, the patience and the personal charisma to lead a team constructing a useful vehicle from the various components, and finally the sheer energy required over a long period of time to achieve something of this size and weight. I found Brij to be an inspirational motivator, and it was a privilege to work with him. Thanks to him, I consider my involvement in this project to have been an immensely satisfying job. 
This text is taken from Bearing Witness: Essays in honour of Brij V. Lal, edited by Doug Munro and Jack Corbett, published 2017 by ANU Press, The Australian National University, Canberra, Australia. 